University of Rhode Island

DigitalCommons@URI

The Rhode Island Current Conditions Index

Economics

$10-2006$

\title{
Rhode Island Current Conditions Index - October 2006
}

Leonard Lardaro

University of Rhode Island, lardaro@uri.edu

Follow this and additional works at: https://digitalcommons.uri.edu/ricci

Part of the Econometrics Commons

Terms of Use

All rights reserved under copyright.

\section{Recommended Citation}

Lardaro, Leonard, "Rhode Island Current Conditions Index -- October 2006" (2006). The Rhode Island Current Conditions Index. Paper 73.

https://digitalcommons.uri.edu/ricci/73

This Article is brought to you for free and open access by the Economics at DigitalCommons@URI. It has been accepted for inclusion in The Rhode Island Current Conditions Index by an authorized administrator of DigitalCommons@URI.For more information, please contact digitalcommons-group@uri.edu. 
Life is never dull when gauging the performance of Rhode Island's economy! During the period earlier this year when our state's economy was in the doldrums, I had concluded that its economic performance was better than it looked statistically. I never dreamed that my assessment would prove to be so correct. For October, the Current Conditions Index jumped all the way to 83 , as 10 of the $12 \mathrm{CCl}$ indicators improved. While this was the second consecutive month where we have exceeded last year's value, October's $\mathrm{CCl}$ value was its largest since July of 2003. For once, all of the indicators that were either close to improving or were in the midst of negative short-term trends appear to have clicked at the same time.

Two indicators failed to improve in October, while a pair that had been weak for quite a while improved. Over the past year, Government Employment has been essentially flat, so October's 1.4 percent decline should come as no surprise. Given the budget deficits we are facing, this indicator should remain weak and possibly decline for several years to come. Similarly, Total Manufacturing Hours have been falling consistently since 2000 , so its October decline of 1.8 percent is

\begin{tabular}{lr}
\multicolumn{2}{c}{ CCI I ndicators - \% Change } \\
Government Employment & -1.4 \\
US Consumer Sentiment & $26.0 \mathbf{Y}$ \\
Single-Unit Permits & $26.3 \mathbf{Y}$ \\
Retail Sales & $2.8 \mathrm{Y}$ \\
Employment Services J obs & $2.5 \mathrm{Y}$ \\
Priv. Serv-Prod Employment & $0.7 \mathrm{Y}$ \\
Total Manufacturing Hours & -1.8 \\
Manufacturing Wage & $2.4 \mathbf{Y}$ \\
Labor Force & $1.0 \mathrm{Y}$ \\
Benefit Exhaustions & $-11.5 \mathbf{Y}$ \\
New Claims & $-0.4 \mathbf{Y}$ \\
Unemployment Rate & $-2.0 \mathrm{Y}$ \\
\multicolumn{1}{|c}{$\mathbf{Y}=$ I mproved Value } &
\end{tabular}

also not surprising. The two pleasant surprises were SingleUnit Permits, which reflect new home construction, and US Consumer Sentiment. Single-Unit Permits rose by 26.3 percent compared to last October, a level almost twice as large as that of September. US Consumer Sentiment rose by 26 percent, its second consecutive monthly rise, aided by declining gasoline and energy prices in October.

Two indicators that have shown ongoing strength also continued to improve. Retail Sales rose by 2.8 percent in October, sustaining its strong upward trend. Along with
September's rise, Retail Sales has shown a great deal of strength during the fall lead up to the holiday season. Benefit Exhaustions, which reflects long-term unemployment, continued to improve, falling by a dramatic 11.5 percent in October. This was aided by favorable showings for Employment Service Jobs, a labor category that includes "temps," which rose by 2.5 percent in October, and another monthly rise in Private Service-Producing Employment, which increased by 0.7 percent. Along with these, there was a slight decline in New Claims for Unemployment Insurance, which measures layoffs, its first improvement in three month.

Rhode Island's manufacturing sector continued to generate conflicting signals. The Manufacturing Wage rose by 2.4 percent in October, its tenth consecutive increase, and its strongest growth rate in several months. But Total Manufacturing Hours fell by 1.8 percent. As I have noted over the past few months, this combination points to the likelihood that labor shortages have begun to emerge that are causing Manufacturing Wage growth to accelerate.

Finally, Labor Force growth remained well below its rates of growth throughout much of this year, rising by 1.0 percent in October, while our Unemployment Rate fell slightly from 5.1 percent last October to 5.0 percent this October.

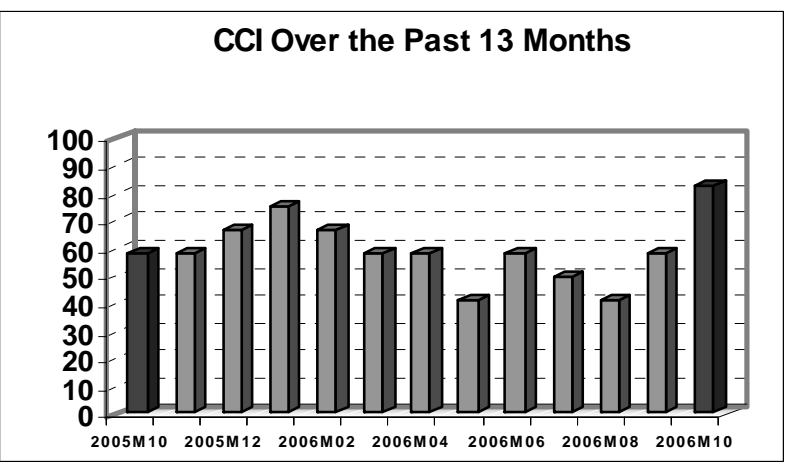

\section{THE BOTTOM LINE}

October's large $\mathrm{CCl}$ rise does not mean Rhode Island's economy has suddenly gotten much stronger. Instead, growth has accelerated, hopefully to "second gear," which will be a challenge to sustain as the national economy slows and we confront state budget deficits.

\begin{tabular}{|c|c|c|c|c|c|c|c|c|c|c|c|c|}
\hline & Jan & Feb & Mar & Apr & May & $J$ un & J ul & Aug & Sep & Oct & Nov & Dec \\
\hline 2005 & 50 & 67 & 50 & 50 & 42 & 75 & 58 & 67 & 42 & 58 & 58 & 67 \\
\hline 2006 & 75 & 67 & 58 & 58 & 42 & 58 & 50 & 42 & 58 & 83 & & \\
\hline
\end{tabular}

